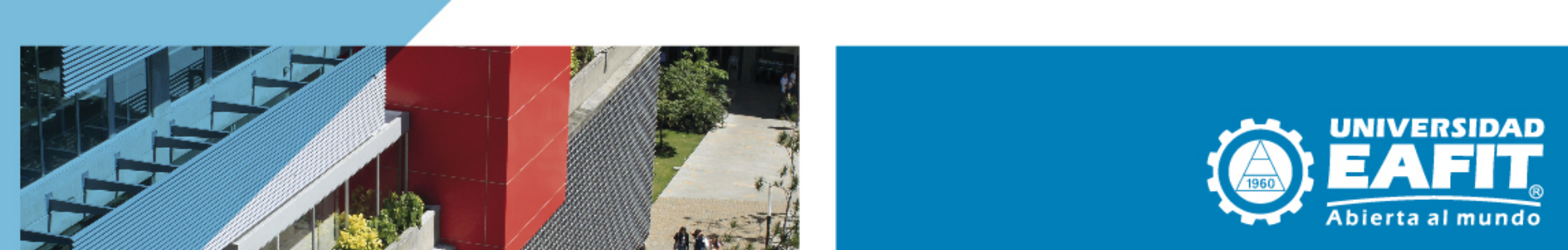

Escuela de Economía y Finanzas

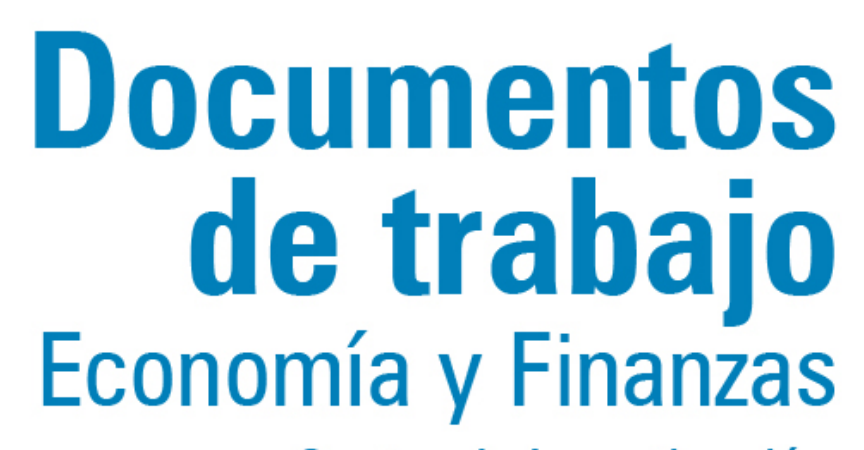

Centro de Investigación Económicas y Financieras

Overvaluation of the real exchange rate

No. 13-28 and the Dutch Disease: the Colombian

2013 case

Goda, Thomas; Torres, Alejandro.

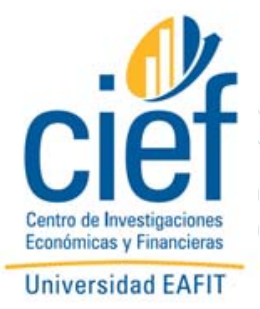




\title{
Overvaluation of the real exchange rate and the Dutch Disease: the Colombian case
}

\author{
by \\ Thomas Goda and Alejandro Torres
}

August 2013

\begin{abstract}
In this study, we estimate the impact of the 2004-2012 energy and mining boom on the real effective exchange rate in Colombia and the sectoral composition of its economy. To this end, we introduce the new "extended Dutch Disease" concept, according to which a currency appreciation may not only occur due to traditional "spending" and "relocation" effects but also due to exports and massive inflows of external capital that finances the booming sector. The empirical results indicate that Colombia experienced an overvaluation of its real exchange rate, which in turn negatively affected the competitiveness of its manufacturing and agricultural sector.
\end{abstract}

Keywords: Dutch Disease, real effective exchange rate, capital flows, de-industrialization, Latin America, Colombia

JEL clasificaciones: F4; O13; O14; O54

\footnotetext{
- Universidad EAFIT, School of Economics and Finance, Carrera 49 Número 7 Sur 50, Medellín, Colombia; Email contact: Thomas Goda (corresponding author), tgoda@eafit.edu.co; Alejandro Torres, atorres7@eafit.edu.co. We would like to thank Natalia Gaviria for her excellent research assistance. Further, we are grateful to Maria Fernanda Quintero, Philip Ueno, an anonymous editor, and the participants of the "Seminario Semanal de Economía del Banco de la República de Colombia (sede Medellín)" and the "Tercer Coloquio Binacional Colombia-Norte de México" for their helpful comments that enabled us to improve our paper.
} 


\section{INTRODUCTION}

Colombia experienced accelerated growth during the first decade of the twenty-first century, which placed it among the new emerging economies of the world. The main reasons for this surge in the country's economic growth are an improved macroeconomic stability, an increase in trade and more financial openness, and ambitious public investment programs. However, the most important reason is the recent global commodity boom that led to a rise in the prices of Colombia's main export products - oil, coal, and gold. As a result of this boom, Colombia's oil and coal exports increased by 2.5 times between 2002 and 2012, while its gold exports grew 6 times (Banco de la República, 2013). Evidently, the resulting favorable economic performance has led to the improvement of general living conditions (such as better health coverage and education), the broadening of the middleclass, and reduction of poverty. However, the sustainability of this growth in the long-run is questionable because the recent decline of the share of industrial and agricultural production in the GDP and the decreasing diversification of Colombia's exports make the country more vulnerable to external shocks.

The sustainability of resource-based growth has long been debated and some academics argue that in the long-run there exists a so-called "natural resource curse", that is, an inverse relationship between resource abundance and growth (see e.g., Sachs and Warner, 1995, 2001; Arezki and van der Ploeg, 2011). A possible transmission channel of this curse is the so-called Dutch Disease theory. This theory states that the boom in one sector of the economy can generate a process of de-industrialization via "spending" and "relocation" effects (Corden and Neary, 1982), which is likely to have negative impacts for the country when the boom subsides. However, these skeptical views are widely debated as economies such as Australia, Canada, the Netherlands, and Norway show that natural resource abundance does not necessarily lead to de-industrialization and that it can also be positive for the development of an economy. In other words, many economists argue that resource abundance per se is neither a curse nor a blessing (see e.g. Lederman and Maloney, 2007, 2008; Brunnschweiler, 2008).

The possible positive and negative impacts of the recent commodity boom in Colombia have been widely discussed among academics and politicians in Colombia and Latin 
America; but, apart from the study of Clavijo et al. (2012), which has a flaw in the methodological design, thus far no other study has empirically examined if the recent commodity boom was a reason behind the declining share of other sectors in Colombia's GDP. Hence, the aim of this study is to add new evidence to the existing debate by assessing the impacts of the commodity boom on the country's manufacturing and agricultural sector.

Typically, existing studies have been concerned about negative impacts for the manufacturing sector as this sector is considered the most important sector for the economic development of a country (see, for example, Corden and Neary, 1982; Bresser Pereira, 2009; Rajan and Subramanian, 2011; Clavijo et al., 2012). The main reason for our novel approach of considering the agricultural sector is that a competitive agricultural sector is becoming increasingly important given that global food prices are currently displaying an upward trend (Belke et al., 2013) and because global food security might be at risk in the future due to climatic changes (Commission on Sustainable Agriculture and Climate Change, 2012). An additional reason is that the consequences of the decline of the agricultural sector are particularly hotly debated in Colombia.

To study the impact that the boom had on these two sectors, we introduce the "extended Dutch Disease" (EDD) concept, which is another novelty of this paper. According to this concept, the real effective exchange rate (REER) may not only be affected by the traditional "spending" and "relocation" effects but also by exports and massive inflows of external capital that are used to finance the exploitation of raw materials. The main idea behind this approach is that potentially the competitiveness of the tradable lagging sectors diminishes if increasing capital inflows and exports lead to an overvaluation of the country's REER. We use three autoregressive distributed lag (ARDL) models in a two-step approach to verify the existence of the EDD phenomenon in Colombia. In the first step, one model is employed to assess if exports and capital inflows led to an overvaluation of the Colombian REER. In the second step, two sectoral models are employed to assess if the appreciation of the REER contributed to the decline of the manufacturing and agricultural sector. 
The results of these models suggest that Colombia indeed experienced an EDD syndrome between 2004 and 2012. Even though many other countries in the region underwent a similar commodity boom, a particular aspect of the Colombian case is that a huge proportion of raw material exploitation has been undertaken and financed by international investors through foreign direct investment (FDI), foreign portfolio investment (FPI), and foreign bank loans. This increase in capital inflows (particularly FDI and bank loans) and exports has led to an overvaluation of the REER that negatively affected the GDP share of the manufacturing and agricultural sector. Therefore, countries like Mexico that want to copy the "Colombian model" and attract private investors to conduct an exploration of commodities (Irwin, 2013) should be cautious and also consider the possible negative effects of this development model. Additional noteworthy findings are that both sectors also suffered from the global recession and the reduction of import tariffs, although their decline cannot be explained by the global trend toward the service sector.

The paper is structured in the following manner: In section two, we discuss important features of the Colombian case. In section three, we present a literature review on the possible economic impacts of raw material exploitation and introduce the EDD concept. In section four, we provide details of the methodology and data used and the chosen sample period. In section five, we discuss the estimation results, and in section six we present the conclusions.

\section{COMMODITY BOOM IN COLOMBIA}

The appreciation of the REER and its effects on the country's competitiveness in noncommodity sectors has been widely discussed in Colombia in recent months, despite the fact that Colombia experienced sustained high growth rates since the beginning of the 2000s (its average growth rate of 4.8\% in the period 2004-2012 was above its long-run trend). The reason for these discussions is that the main driving force behind this growth was a commodity boom: between 2002 and 2012 annual oil exports increased from 100 
million to 250 million barrels, coal exports from 32 to 77 million metric tons, and gold exports from 411,000 to 2.5 million troy ounces (Banco de la República, 2013).

This boom can be explained mainly by three factors: (i) the hike in global commodity prices, (ii) Colombia's economic liberalization policies, and (iii) its promotion of foreign investment inflows. Arguably, the most important among these three factors was the increase in commodity prices: in the period January 2002 to December 2012, the price of one barrel of crude oil increased from US\$ 19 to US\$ 101, the price of one metric ton of coal increased from US\$ 31 to US\$ 82, and the price of one ounce of gold increased from US\$ 282 to US\$1,685. In addition to these favorable price changes, Colombia fostered its trading activities by signing various free trade agreements in recent years with the United States, Chile, South Korea, the European Union, and Panama. Finally, Colombia liberalized its financial markets and promoted capital inflows by strengthening its legal framework and providing incentives to foreign investors (like tax holidays).

One of the outcomes of these three developments was a steady increase in capital inflows that were mainly directed to the energy and mining sector with the aim to take advantage of the relatively high yields that could be achieved (see Fig. 1a). These investments further fuelled the production boom, particularly after 2007, with the result that the amount of fuel and mining exports increased from 4\% of GDP in 1998 to 14\% in 2012 (Fig. 1b). This increase in production also implied that the share of the energy and mining sector in the country's GDP increased by almost 10 percentage points after 1998, whereas that of the manufacturing and agricultural sector ${ }^{1}$ declined considerably (Fig. 1c). After 2003, all these developments were accompanied by a strong appreciation of Colombia's REER (Fig. 1d), which raises the question of whether the appreciation contributed to the decline of the agricultural and manufacturing sector. 

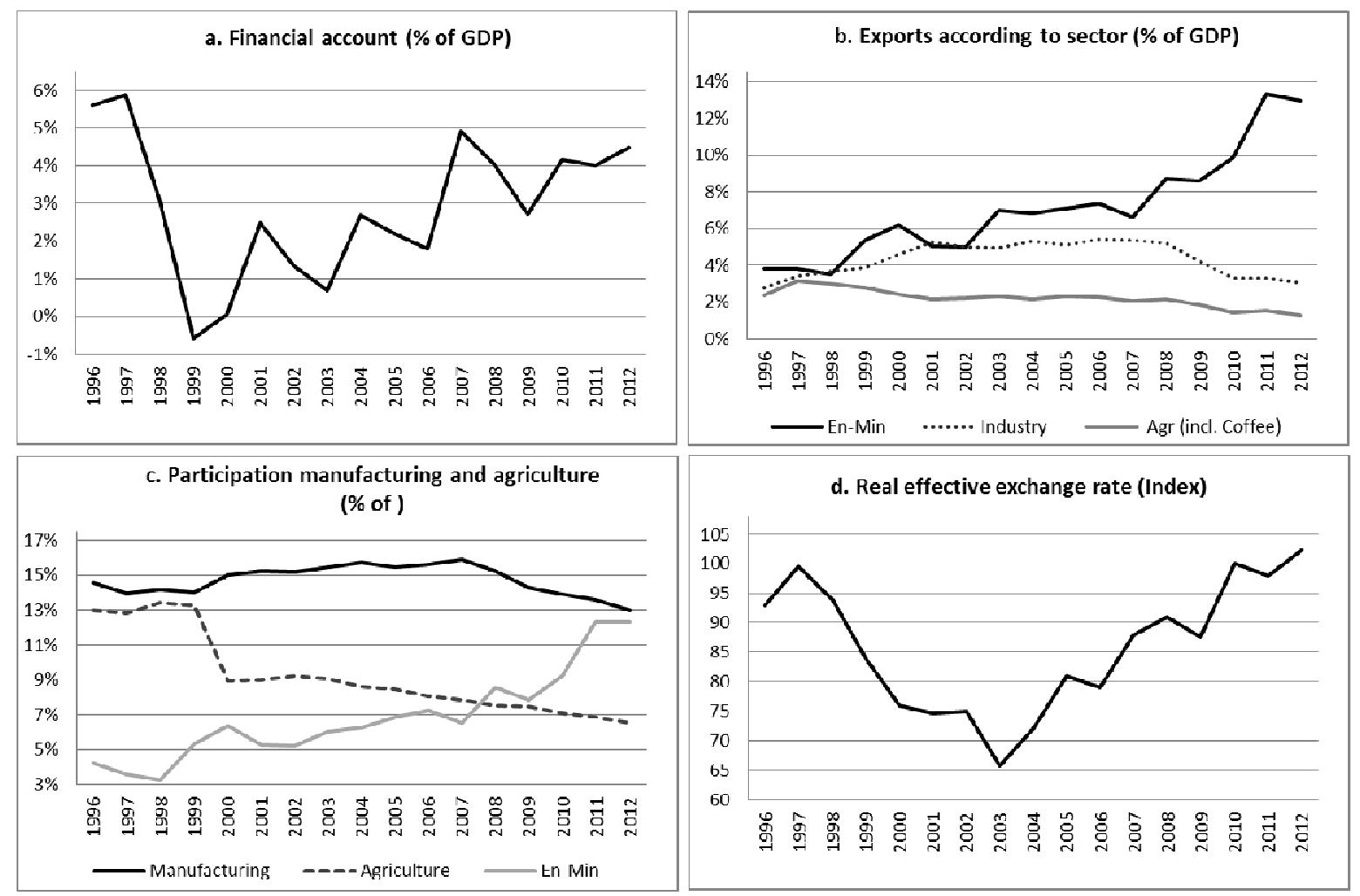

Fig. 1. Evolution of selected Colombian macroeconomic variables (1996-2012). This graph shows the changes in (i) Colombia's financial account balance as a percentage of GDP (top left), (ii) its exports as a percentage of GDP according to selected sectors (top right), (iii) the participation of selected sectors in overall production (bottom left), and (iv) its REER based on weighted bilateral exchange rates with a basket of 61 countries. En-Min stands for the energy and mining sector, and Agr for the agricultural sector (Source: Banco de la República, DANE and BIS; own calculations).

To the best of our knowledge, thus far only one study of Clavijo et al. (2012) investigates this question empirically. Using a vector error correction model (VECM), the authors find that the decline of Colombia's industrial sector between 1965 and 2012 is related to the export dynamics of the energy and mining sector, commercial openness, and the appreciation of the REER; they conclude that the country is currently facing Dutch Disease problems. However, their analysis does not consider the agricultural sector and, more importantly, it does not fit appropriately with the Dutch Disease phenomena as described by Corden and Neary (1982) because they assume that it is the appreciation of the REER that leads to the de-industrialization process, while Corden and Neary state that the former is a consequence of the latter (this will be discussed in detail in the next section). 
On the contrary, studies that evaluate changes in Colombia's REER do not relate their results to the sectoral composition of the country's economy. For example, Echavarría et al.'s (2008) study attempts to identify the country's equilibrium REER for the period 19852005 by using a structural VECM; the authors find that Colombia experienced an "overappreciation" in the last portion of the sample period due to "excess" government spending and higher foreign capital inflows. However, the authors do not associate the commodity boom with these findings. In the following section we thus intend to outline a new theoretical framework that describes the possible interrelation among a boom, the appreciation of the REER, and the sectoral recomposition of an economy.

\section{RAW MATERIAL EXPLOITATION, OVERVALUATION OF THE REER,}

\section{AND SECTORAL CHANGE}

The interrelation among natural resource booms, industrialization, and long-term economic growth has been analyzed for decades. One of the first studies that developed a theory related to the so-called "natural resource curse" was Prebisch (1950), who stated that the long-term costs that are related to the production of raw materials and food are higher than the resultant benefits because over time there is a deterioration in the terms of trade for primary products, which makes the import of industrial goods increasingly expensive and thus sustained high growth rates unlikely. Accordingly, it would be preferable for a country to increase its industrial production and decrease its dependence on primary exports.

To a certain extent, this policy recommendation is backed by the empirical findings of Sachs and Warner (1995, 2001) and Arezki and van der Ploeg (2011), who report a negative relationship between resource abundance and economic growth. According to Gelb (1988), this inverse relationship can partially be explained by the increase in public revenue that causes fiscal and macroeconomic disequilibria, whereas Gylfason (2001) and Lederman and Maloney (2007) state that the dependence on natural resources can lead to lower productivity growth due to disincentives to foster human capital formation and investment. Finally, Lederman and Maloney (2008) and Lopez (2012) argue that the 
vulnerability to external price shocks is an explanatory factor for the low growth of countries with natural resource abundance that have not sufficiently diversified their production and export basket. $^{2}$

Nevertheless, the most widely discussed mechanism that could explain the poor longrun growth performance of many resource rich countries is the so-called Dutch Disease effect, first formalized by Corden and Neary (1982) in its "conventional" form and hereafter referred to as CDD. According to their findings, a boom in the raw material sector tends to have positive impacts on the non-tradable sector, whereas it has negative impacts on the so-called lagging sectors that also produce tradables through "spending" and "resource movement" effects. The first effect refers to an increase in demand for nontradables as the extra income from the booming sector is partially spent on non-tradables, whereas the second effect refers to the movement of labor out of the lagging sector into the booming and non-tradable sector. Both effects cause a decline in the lagging sectors and appreciation of the REER. This CDD theory was first augmented by Corden (1984), who introduces an open economy case in which an additional "spending" effect can be generated by an increase of exports from the booming sector.

More recently, the definition of the Dutch Disease phenomena has been widened even further. Firstly, the Dutch Disease is not any longer necessarily restricted to a booming sector; secondly, an appreciation of the REER is considered an additional transmission mechanism for the decline of the lagging sectors. Recent empirical studies such as Ibarra (2011) and Naceur et al. (2012) show that financial account inflows like FDI and FPI can lead to an appreciation of the REER, and Bresser Pereira (2009) argues that such inflows can generate an overvaluation of the exchange rate that causes a decline in the industrial sector when they are related to a commodity boom. On the other hand, Rajan and Subramanian (2011) and Fielding and Gibson (2013) consider that huge inflows of foreign aid can generate a "spending" effect that leads to the appreciation of the REER which, in turn, diminishes the competitiveness of the country's tradable sectors. Finally, Bourdet and Falck (2006), Bayangos and Jansen (2011), and Lartey et al. (2012) argue that remittance inflows can have the same effect. 
In other words, an appreciation of the REER potentially plays a double role with regard to sectoral composition. In the CDD theory the appreciation of the REER is only considered an outcome of price adjustments between tradables and non-tradables, whereas in its contemporary version, it is assumed that an appreciation by itself can be a cause for the decline of the lagging sectors. One can therefore argue that the emergence of a boom can lead to an appreciation of the REER and that this appreciation can simultaneously cause loss of competitiveness of lagging sectors.

According to the CDD theory, a regression between the sectoral composition and the REER would make no sense as the decline of the sectors occurs due to "spending" and "resource allocation" effects. However, if the REER "overreacts" during a boom (i.e., if it is above its equilibrium value) an appreciation may well play an additional role in the recomposition of the economy because lagging sectors would be additionally hurt by a loss of competitiveness. Hence, a country suffers from the EDD syndrome, as we call it $^{3}$, (i) if an increase in boom-related capital inflows and export revenue cause an "overappreciation" of the REER and (ii) if this "overappreciation" affects the competitiveness of other tradable sectors negatively (see Fig. 2).

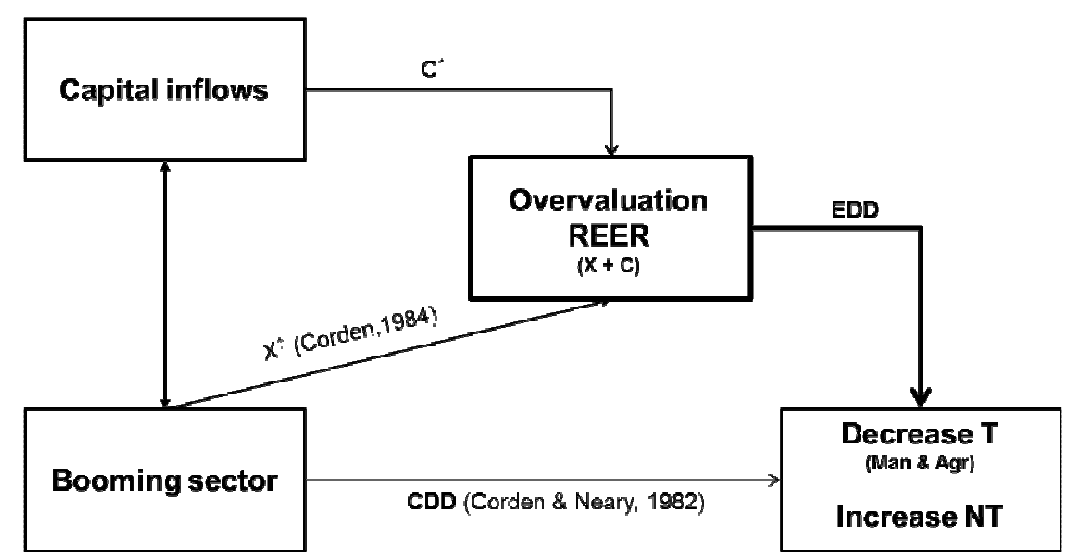

Fig. 2. Mechanisms of the "conventional" and the "extended" Dutch Disease. This schematic representation depicts the "conventional" direct effect that a booming sector can have on tradable (T) and non-tradable (NT) sectors as well as the possible "extended" indirect effect via an overvaluation of the REER that is caused by an increase in exports (X) and capital inflows (C). "Man" stands for manufacturing and "Agr" for Agriculture.

This interplay is precisely the reason why we have chosen Colombia for our empirical exercise (the country is witnessing a massive inflow of boom-related capital, a strong 
increase in commodity exports, and a significant decline in the lagging sectors, as we have seen above). To test if Colombia has indeed experienced the EDD phenomenon, we apply an empirical strategy that comprises two steps: In the first step, we verify if the REER in Colombia experienced an overvaluation during the boom period, taking into account conventional variables, net inflows of capital, and the trade balance. In the second step, we test if the decline of the Colombian manufacturing and agricultural sector is related to the appreciation of the REER.

\section{METHODOLOGY AND DATA}

\section{(a) Rationale for the models}

Recent research has identified several determinants that explain changes in the REER (see e.g. Ibarra, 2011; Treviño, 2011; Naceur et al., 2012). Two often stated fundamentals are changes in productivity and higher government consumption. The rationale behind the inclusion of former variable is that a rise in relative productivity in the tradable sector is expected to lead to an appreciation in the REER through the Balassa-Samuelson effect. The same is true for an increase in government consumption if this consumption mainly includes non-tradable goods and services. However, government consumption can also have depreciating effects if the spending causes a deterioration in the fiscal balance.

In addition to these two variables, an increase in commodity prices, positive trade balance, and net capital inflows are also expected to cause currency appreciation (as discussed above). Finally, interest rate differentials and reserve accumulation are also considered important: if a country has higher interest rates than the rest of the world, it is predicted that there is an increase in capital inflows and an appreciation of the nominal exchange rate; whereas foreign reserve accumulation increases the supply of the domestic currency, which should lead to depreciation in nominal terms. In sum, our REER model can be represented by the following equation:

$$
R E E R=f(P R O D, G O V, i, C O M, T B, F I, R E S)
$$


where $P R O D$ denotes relative productivity, $G O V$ relative government consumption, $i$ interest rate differentials, $C O M$ commodity prices, $T B$ the net trade balance, FI financial net inflows, and RES changes in foreign reserves.

Once it is determined if the REER has been overvalued, the next step is to verify the reasons for sectoral recomposition. It is well established that an overvaluation can have negative impacts on the performance of the tradable sector (see, for example, Aguirre and Calderón, 2005; Rodrik, 2008; Eichengreen, 2007; Frenkel and Rapetti, 2012). Moreover, recent studies suggest that a decrease in tariffs (Rajan and Subramanian, 2011), lower global growth figures, and higher production costs (Hodge, 2012) may cause the decline of the tradable sector. Finally, a sectoral recomposition might also mirror a global phenomenon - that is, a general shift away from traditional production sectors to the service sector (Szirmai et al., 2013). Thus, our two sectoral models can be represented by the following equation:

$$
\text { SECTOR }=f(R E E R, T, \text { GROWTH, COST,WORLD })
$$

where SECTOR denotes the GDP share of the manufacturing or agricultural sector, $T$ average import tariffs, GROWTH global growth rates, COST production costs, and WORLD the average global GDP share of the respective sector.

Given that many of the abovementioned variables are non-stationary according to unreported augmented Dickey-Fuller (ADF) unit root tests ${ }^{4}$, stationary vector autoregression (VAR) and VECM models would be preferable for our purposes to a singleequation ordinary least squares (OLS) specification. However, the Johansen procedure requires that all variables are integrated of order one, which is very unlikely in our case. Moreover, we find it impractical to apply the Johansen test as the large number of variables and our limited sample size (i.e., a maximum of 65 observations) would make the degrees of freedom far too small ${ }^{5}$.

Therefore, we follow Ibarra (2011) and employ an ARDL error correction model and use Pesaran et al.'s (2001) bounds testing procedure to assess if the level variables in our 
models are cointegrated. This method allows us to incorporate (simultaneously) all the above-mentioned determinants. Furthermore, the advantage of this modeling technique is that it produces consistent estimates of long-run coefficients independently of their order of integration (Pesaran and Shin, 1995), while it simultaneously corrects for any weak endogeneity of regressors (Shin et al., 2013) ${ }^{6}$. Hence, we believe that the following general model form is the most suitable for our approach (the current and lagged differenced variables measure short-run effects, while the lagged-level variables account for long-run effects):

$$
\Delta \alpha_{t}=\beta_{0}+\sum_{i=0}^{p} \gamma_{1 i} \Delta X_{1 t-i}+\cdots+\sum_{i=0}^{p} \gamma_{K i} \Delta X_{K t-i}+\sum_{i=1}^{p} \delta_{i} \Delta \alpha_{t-i}+\delta_{0} \alpha_{t-1}+\sum_{k=1}^{K} \beta_{k} X_{k t-1}+u_{t}
$$

\section{(b) Data and sample period}

For reasons related to data availability, our sample period for the REER model and the manufacturing model spans from the first quarter of 1996 to the last quarter of 2012. Our agricultural model has a shorter observation period - from the first quarter of 2000 to the last quarter of 2012. The reason for this is that, in 2000, Colombia's National Institute of Statistics (DANE) changed its methodology, which did not affect the manufacturing sector data but did affect the agricultural sector data (see Fig. 1c $)^{7,8}$. Since most of the relevant data are not available on a monthly basis, we utilize quarterly data ${ }^{9}$.

As a proxy for the REER we take the quarterly averages of the readily available broad effective exchange rate index from the Bank of International Settlement (BIS). In line with Ibarra (2011), we include the ratio of the Colombian industrial production index to the US industrial production index as a proxy for changes in the relative productivity in the tradable sector (retrieved from DANE and from Data-FRED) ${ }^{10}$, while government consumption is measured by the ratio of Colombian over US government consumption, both normalized with the respective GDP (retrieved from DANE and the US Bureau of Labor Statistics). To account for the impact of changes in capital inflows on the REER, we consider total net financial account inflows, net foreign direct investment, net foreign portfolio investment, net other capital investment, and net payments (retrieved from 
Colombia's Central Bank Balance of Payments (BoP) data). As in Ibarra (2011), all these data are normalized by quarterly GDP at purchasing power parity $(\mathrm{PPP})^{11}$ to avoid spurious correlation between capital inflows and the REER. The same methodology is applied to account for changes in foreign reserve holdings and the net trade balance.

In addition, a self-created weighted commodity price index that comprises the three main commodity exports of Colombia is included in the model. The index takes into account quarterly price averages and quarterly export shares of oil, coal, and gold (prices are retrieved from the World Bank and export shares from Colombia's BoP data). Finally, we test for the significance of the difference between the Colombian average quarterly lending interest rate ${ }^{12}$ (retrieved from the Colombian National Planning Department and the Colombian Central bank) and the average quarterly London Interbank Offered Rate (LIBOR) to consider the possible effects of interest rate differentials.

With regard to the two sectorial models, our respective dependent variables are the manufacturing share and the agricultural share as a percentage of current GDP (the data are retrieved from DANE). Further, as a proxy for the REER, we employ the quarterly averages of the BIS REER index, and, in line with Hodge (2012), we consider quarterly OECD growth rates to account for changes in global growth (retrieved from OECD StatExtracts). Our measure for import tariffs is the applied weighted mean tariff rate for manufactured products and primary products (reported by the World Development Indicators $)^{13}$. Finally, we consider the quarterly averages of Colombia's Central Bank producer price indexes for manufacturing and agriculture as proxies for changes in production costs in the two sectors.

\section{(c) Model selection}

Given that the sample size is relatively small, we decided to begin with a reduced form of the model in which subsequently more explanatory variables were introduced to establish our favored parsimonious model. Due to the quarterly frequency of the data, the four lagged differences of each variable were also included and, based on an F-test, all 
jointly insignificant lags of the differences of this variable were excluded. Our final favored models have a better fit and/or lower Schwarz criterion than the other specifications and consider only variables that are significant (reported in the results section as (vii) in Table 1, and (vi) in Tables 4 and 5).

To test for possible breakpoints in our sample, Quandt-Andrew breakpoint tests $(25 \%$ trimming) were conducted for the first specification of all three models. According to these tests each model has a structural shift (at least at the $10 \%$ level $^{14}$ ); the maximum likelihood for a break is the third quarter of 2008 in the REER model, the third quarter of 2004 in the manufacturing model, and the third quarter of 2003 in the agricultural model. A possible reason for the structural break in the REER model is the beginning of the global Great Recession, whereas the break in the manufacturing and agricultural models can be explained by the change from a depreciating to an appreciating regime that occurred in Colombia between 2003 and 2004 (see Fig. 1d). Considering these results and the plausible explanations for them, we believe that it is reasonable to take these breakpoints into account in our modeling strategy.

Hence, shift variables for all independent variables were created and tested for significance $^{15}$. In all resultant specifications (reported in Tables 2, 4, and 5), the long-run error coefficient is highly significant and negative, the models show no evident misspecification and mutual cointegration is accepted by the bounds F-test. In our three parsimonious models, the bounds F-test is accepted at the $1 \%$ level and the bounds t-test at least at the 5\% level, which strongly indicates cointegration irrespective of whether the regressors are stationary or non-stationary. Furthermore, the appropriate functional form is linear according to Ramsey's Reset test, and the Wu-Hausman test indicates that all contemporaneous variables are weakly exogenous. 


\section{RESULTS}

\section{(b) Real effective exchange rate model}

The obtained results indicate that most of the variations in Colombia's REER can be explained by the fundamental variable of relative productivity, which is consistent with the Balassa-Samuelson hypothesis and with the results of other studies like Echavarria et al. (2008), Naceaur et al. (2012) and Ibarra (2011). In other words, as expected, an increase in Colombia's relative productivity leads to a strong appreciation of its REER in the long-run. On the contrary, the other variable that is often related to the equilibrium long-run behavior of the REER - relative government spending - is not significant in any of the specifications; whereas our proxy for interest rate differentials (i-LIBOR) is significant in all specifications and has the expected sign (see Table 1). The latter finding is in line with Ibarra's (2011) results. The result that relative government spending is not significant is surprising and contrary to Echavarría et al.'s (2008) results; however, it is beyond the scope of our paper to examine the potential reasons for this finding.

Nevertheless, to verify the overvaluation hypothesis, the results of the trade balance and financial account variables are the most important because an increase in exports and/or capital inflows can potentially lead to a deviation in the REER with respect to the fundamentals, as discussed above. To be more precise, if the coefficients of both variables are significant and positive, it can be concluded that the exchange rate is overvalued. In the Colombian case, the trade balance (TB) variable is positive and highly significant in all specifications, which is in line with Corden's (1984) export surplus hypothesis. The second variable of interest, the financial account balance (FAB) is also significant and has the expected sign. The variable loses its significance though when the lagged level of net payments and changes in foreign reserve holdings are introduced simultaneously into the model (models (iv) and (v) in Table 1). However, since two latter variables have a lower tstatistic than the FAB variable and unexpected signs ${ }^{16}$, they are excluded to obtain the parsimonious model. In sum, the results of our favored parsimonious model (model (vii) in Table 1) suggest that Colombia witnessed an overvaluation phenomenon that was related to the boom in its mining and energy sector. 
Table 1

REER model for Colombia

\begin{tabular}{|c|c|c|c|c|c|c|c|}
\hline & (i) & (ii) & (iii) & (iv) & (v) & (vi) & (vii) \\
\hline$\Delta(\operatorname{REER}(-2))$ & $-0.2786 * * *(-2.69)$ & $-0.2955 * * *(-2.95)$ & $-0.2766 * * *(-2.84)$ & $-0.2937 * * *(-3.02)$ & $-0.2616^{* * *}(-2.76)$ & $-0.2605^{* *}(-2.84)$ & $-0.2907 * * *(-3.10)$ \\
\hline$\Delta(\operatorname{IPR}(-1))$ & $-0.4980 * * *(-3.00)$ & $-0.2060 \quad(-1.04)$ & & $-0.1545 \quad(-0.77)$ & & & \\
\hline$\triangle \mathrm{FAB}(-2)$ & & $0.5921 * * \quad(2.03)$ & & $0.6583 * * \quad(2.37)$ & & & $0.7372 * * * \quad(2.85)$ \\
\hline$\Delta \mathrm{FDI}$ & & & $0.7362^{*} \quad(1.69)$ & & $1.0951 * * \quad(2.53)$ & $1.0771^{* *} \quad(2.64)$ & \\
\hline$\triangle O \mathrm{OTHER}^{\mathrm{S8Q3}}$ & & & $1.2609 * * * \quad(2.84)$ & & $1.0212^{* *} \quad(2.43)$ & $0.9924^{* *} \quad(2.41)$ & \\
\hline$\triangle O T H E R(-2)$ & & & $0.6206 * * * \quad(2.82)$ & & $0.5150 * * \quad(2.38)$ & $0.4953^{* *} \quad(2.35)$ & \\
\hline$\Delta \mathrm{FR}(-4)$ & & & & $-0.7674 * * \quad(-2.35)$ & $-0.7735^{* *} \quad(-2.40)$ & $-0.8014 * * \quad(-2.56)$ & $-0.8342 * * *(-2.71)$ \\
\hline$\Delta \mathrm{FR}(-4)^{\mathrm{s} 8 \mathrm{Q} 3}$ & & & & $2.0545^{* *} \quad(2.19)$ & $2.1733^{* *} \quad(2.20)$ & $2.4106^{* *} \quad(2.58)$ & $2.2611^{* *} \quad(2.52)$ \\
\hline $\operatorname{REER}(-1)$ & $-0.2862 * * *(-4.26)$ & $-0.2902 * * *(-4.31)$ & $-0.2745^{* * *}(-4.24)$ & $-0.2435 * * *(-3.69)$ & $-0.2247 * * *(-3.48)$ & $-0.2116 * * *(-3.70)$ & $-0.2189 * * *(-3.84)$ \\
\hline $\operatorname{REER}(-1)^{\mathrm{s} 8 \mathrm{Q} 3}$ & $-0.1673^{* * *}(-2.82)$ & $-0.1535^{* * *}(-2.67)$ & $-0.1628 * * *(-2.75)$ & $-0.1035^{* * *}(-4.35)$ & $-0.0910 * * *(-3.67)$ & $-0.0916 * * *(-4.25)$ & $-0.1044 * * *(-5.23)$ \\
\hline $\mathrm{FAB}(-1)$ & 0.6672 & $0.7660^{*}$ & & 0.7571 & & & $1.0938^{* *} \quad(2.57)$ \\
\hline FDI(-1) & & & $0.9828 * \quad(1.71)$ & & 0.9107 & $1.3296 * * \quad(2.43)$ & \\
\hline $\mathrm{FPI}(-1)$ & & & $0.2621 \quad(0.50)$ & & $0.3447 \quad(0.35)$ & $0.7352 \quad(1.49)$ & \\
\hline OTHER(-1) & & & $1.0824 * * \quad(2.62)$ & & 0.9427 & $1.4190 * * * \quad(3.15)$ & \\
\hline $\mathrm{TB}(-1)$ & $2.9104 * * * \quad(3.60)$ & $3.5720 * * * \quad(4.36)$ & $3.0655^{* * *} \quad(3.75)$ & $3.5660 * * * \quad(2.70)$ & $3.1192 * * \quad(2.45)$ & $3.4226 * * * \quad(4.69)$ & $3.7949 * * * \quad(5.32)$ \\
\hline $\operatorname{IPR}(-1)$ & $0.5593 * * * \quad(5.87)$ & $0.5692 * * * \quad(6.17)$ & $0.4957^{* * *} \quad(5.79)$ & $0.5288 * * * \quad(5.96)$ & $0.4628^{* * *} \quad(5.56)$ & $0.4484 * * * \quad(6.01)$ & $0.5005^{* * *} \quad(6.76)$ \\
\hline i-LIBOR(-1) & & $0.3069 * \quad(1.96)$ & $0.3513^{* * *} \quad(2.78)$ & $0.3579 * * \quad(2.35)$ & $0.3905^{* * *} \quad(3.17)$ & $0.4022 * * * \quad(3.42)$ & $0.4229 * * * \quad(3.45)$ \\
\hline $\operatorname{com}(-1)$ & $-0.0278 \quad(-1.29)$ & $\begin{array}{ll}-0.0061 & (-0.26)\end{array}$ & $\begin{array}{ll}-0.0039 & (-0.17)\end{array}$ & & & & \\
\hline $\operatorname{COM}(-1)^{\mathrm{s} 8 \mathrm{Q} 3}$ & 0.0588 & 0.0318 & 0.0448 & & & & \\
\hline $\operatorname{GOV}(-1)$ & & $\begin{array}{ll}-4.0262 & (-1.07)\end{array}$ & -5.2535 & -2.9588 & -3.6873 & & \\
\hline$N P(-1)$ & & & & -0.0563 & -0.1902 & & \\
\hline $\mathrm{FR}(-1)$ & & & & $0.4808 \quad(0.44)$ & $0.5937 \quad(0.56)$ & & \\
\hline Sample: & $1996 \mathrm{Q} 4 \mathrm{tc}$ & to $2012 \mathrm{Q} 4$ ( 65 obser & vations) & & $1997 Q 2$ to $2012 Q 4$ & (63 observations) & \\
\hline Adj. $R^{2}$ & 0.44 & 0.48 & 0.53 & 0.53 & 0.57 & 0.58 & 0.55 \\
\hline Schwarz crit. & 5.62 & 5.68 & 5.71 & 5.69 & 5.72 & 5.56 & 5.46 \\
\hline BG(4) prob. & 0.70 & 0.70 & 0.83 & 0.88 & 0.91 & 0.97 & 0.97 \\
\hline Jarq.-Bera prob. & 0.55 & 0.62 & 0.30 & 0.22 & 0.11 & 0.09 & 0.11 \\
\hline Arch(1) prob. & 0.62 & 0.28 & 0.82 & 0.13 & 0.36 & 0.49 & 0.15 \\
\hline White prob. & 0.45 & 0.38 & 0.29 & 0.34 & 0.47 & 0.18 & 0.40 \\
\hline Ramsey LR prob. & 0.35 & 0.11 & 0.66 & 0.05 & 0.05 & 0.06 & 0.11 \\
\hline Wu-Haus. prob. & - & - & 0.73 & - & 0.31 & 0.34 & - \\
\hline Bounds F-stat. & $7.62^{* * *}$ & $6.82^{* * *}$ & $6.01 * * *$ & $6.41 * * *$ & $5.91^{* * *}$ & $6.77^{* * *}$ & $10.39 * * *$ \\
\hline Bounds t-stat. & $-4.58^{* *}$ & $-4.59 *$ & $-4.76^{*}$ & $-4.92 * *$ & -4.60 & $-5.38 * * *$ & $-5.61 * * *$ \\
\hline
\end{tabular}

This table summarizes the results of our ARDL-model for Colombia's REER. Where $\Delta$ is the difference operator, the number of lags are indicated in parentheses as a suffix to a variable's name, $s^{8 Q 3}$ indicates the shift component of a variable and the date of the structural break (i.e., third quarter 2008), REER is the real effective exchange rate of Colombia, $F A B$ is Colombia's financial account balance/GDP at PPP, FDI is Colombia's foreign direct investment balance/GDP at PPP, OTHER is Colombia's other financial flows balance/GDP at PPP, $T B$ is Colombia's trade balance/GDP at PPP, IPR is a relative productivity index, $i$ $\angle I B O R$ is a measure of interest rate differentials, COM is a commodity price index, GOV is Colombia's relative government consumption, $N P$ is Colombia's net payments balance/GDP at PPP, and $F R$ is Colombia's foreign reserve holdings/GDP at PPP. Intercepts are not reported but are included in the models. Coefficients and t-statistics (in parenthesis) are reported in each column. Probability values for all misspecification tests are reported in the lower section of the table, where BG(4) denotes the probability value of the Breusch-Godfrey test for 4 order correlation and $\operatorname{Arch}(1)$ the probability value of the ARCH heteroskedasticity test with 1 lag. The $5 \%$ critical values for the bounds cointegration test with unrestricted intercept and no trend are $\mathrm{F}=3.79, \mathrm{t}=4.19(\mathrm{k}=5) ; \mathrm{F}=3.61, \mathrm{t}=4.38(\mathrm{~K}=6) ; \mathrm{F}=3.5, \mathrm{t}=4.57(\mathrm{k}=7) ; \mathrm{F}=$ $3.39, \mathrm{t}=4.72(\mathrm{k}=8) ; \mathrm{F}=3.24, \mathrm{t}=5.03(\mathrm{k}=10)-$ see Pesaran et al. $(2001)$. The significance of a coefficient or test statistic at the $1 \%, 5 \%$ and $10 \%$ levels of significance is indicated by $* * * * *$ and $*$, respectively.

An additional noteworthy result is that net FDI and net other inflows are the main drivers of the post-2003 capital inflow appreciation effect in Colombia (see model (vi) in 
Table 1$)^{17}$. This result is contrary to Naceur et al.'s findings, but in line with Ibarra's (2011) results. Naceur et al. report that an increase in FDI inflows did not lead to an appreciation of the REER in their sample of 57 developing countries, while FPI and remittances inflows did, whereas Ibarra (2011) concludes that FDI inflows were the most important capital flow in explaining the REER appreciation in Mexico between 1988 and 2008. One reason for these diverging results could be inter-country differences with regard to the sophistication of financial markets (see Saborowski's, 2009 and Lartey, 2011 ${ }^{18}$ ). Another reason could be that FDI inflows have had only minor technological spillover effects in countries such as Colombia and Mexico because commodity-related FDI often operates in "foreign enclaves" that have minimal connection with domestic firms (see, for example, Arias et al., 2013).

To identify which of the variables were mainly responsible for the REER appreciation during the boom, we calculated the marginal cumulative impact (MCI) of all variables in the appreciation period. The MCI is each variable's contribution to the REER relative to a chosen reference point (in this case, the last quarter of 2003) and depends on the changes in the values of the variable and on the respective differenced and lagged-level coefficients. The following formula was used for calculating each quarter's MCI:

$$
\begin{gathered}
\text { Impact }_{\gamma t}=\beta_{\gamma 1} \Delta \gamma_{t}+\beta_{\gamma 1}^{\text {shift }} \Delta \gamma_{t}+\cdots+\beta_{\gamma 4} \Delta \gamma_{t-4}+\beta_{\gamma 4}^{s h i f t} \Delta \gamma_{t-4}+\beta_{\gamma \mathrm{s}} \gamma_{t-1}+\beta_{\gamma \mathrm{s}}^{\text {shift }} \boldsymbol{\gamma}_{t-1} \\
M C l_{\gamma t}=\text { Impact }_{\gamma t}-\text { Impact }_{\gamma 2 \text { govq } 4}
\end{gathered}
$$

Table 2 (upper part) shows that between the first quarter of 2004 and the last quarter of 2012, the increase in relative productivity was mainly responsible for the appreciation of the REER in Colombia, with a maximum MCI of almost 15 index points (ip), whereas interest rate differentials only had a relative minor maximum impact of 1 ip. Most importantly, the maximum impact of net financial account inflows and exports was considerable and led to an REER overvaluation of 3.7 ip and 3.5 ip, respectively. 
Table 2

Maximum MCI according to the parsimonious models (2004Q1-2012Q)

\begin{tabular}{|c|c|c|c|}
\hline & & & \\
\hline & IPR & $14.70 \mathrm{ip}$ & \\
\hline & FAB & $3.66 \mathrm{ip}$ & \\
\hline & TB & $3.48 \mathrm{ip}$ & \\
\hline & i-LIBOR & 1.07 ip & \\
\hline Manufactu & ng sector & Agricultu & sector \\
\hline REER & $-0.93 p p$ & REER & $-0.80 p p$ \\
\hline TARIF & $-0.44 p p$ & TARIF & $-0.27 p p$ \\
\hline GROWTH & $-0.46 p p$ & GROWTH & $-0.13 p p$ \\
\hline
\end{tabular}

This table reports the maximum impact that the explanatory variables have had on the Colombian REER and the GDP share of the manufacturing and agricultural sector in Colombia during the period 2004Q1 and 2012Q4, according to our favored parsimonious model (Table 1 (vii), and (vi) in Tables 3 and 4).

\section{(b) Sectoral models}

After having verified that the REER was overvalued during the recent boom, it is necessary to test if the appreciation has had negative impacts for the two lagging sectors - manufacturing and agriculture - to confirm the existence of an EDD syndrome in Colombia. According to the results of the manufacturing sector model, the REER variable is highly significant in all specifications and has the expected sign. Further, the appreciation of the REER explains most of the decline of this sector during the boom, as shown in model (i) in Table 3. Consequently, the maximum MCI of the REER is the highest of all variables with a value of -0.93 percentage points ( $\mathrm{pp}$ ) (see Table 2 , lower part). In other words, our results imply that the overvaluation of the REER caused an EDD syndrome in the manufacturing sector in Colombia. 


\section{Table 3}

Model for the manufacturing sector's share in the GDP of Colombia

\begin{tabular}{|c|c|c|c|c|c|c|}
\hline & (i) & (ii) & (iii) & (iv) & (v) & (vi) \\
\hline$\triangle \mathrm{MAN}(-1)$ & $-0.3079 * * *(-3.30)$ & $-0.2640 * * *(-2.80)$ & $-0.2974 * * *(-3.23)$ & $-0.3147 * * *(-3.35)$ & $-0.3578 * * *(-3.64)$ & $-0.2896 * * *(-3.22)$ \\
\hline$\Delta \mathrm{MAN}(-4)^{4 \mathrm{Q} 3}$ & $0.6067 * * * \quad(5.50)$ & $0.6364^{* * *} \quad(5.76)$ & $0.5885^{* * *}$ & $0.5523^{* * *}$ & $0.5863 * * * \quad(5.16)$ & $0.5579 * * * \quad(5.08)$ \\
\hline$\triangle$ REER & $-0.0003^{* * *}(-3.37)$ & $-0.0257 * * *(-3.25)$ & $-0.0263 * * *(-3.50)$ & $-0.0316 * * *(-3.64)$ & $-0.0362^{* * *}$ & $-0.0343 * * *(-4.05)$ \\
\hline$\triangle \operatorname{REER}(-2)^{4 Q 3}$ & $0.0003^{* *} \quad(2.30)$ & $0.0228 * * \quad(1.96)$ & 0.0176 & 0.0138 & 0.0127 & \\
\hline$\triangle I P P \_M A N$ & & & & -0.0352 & $-0.0399 *$ & $-0.0366^{*}$ \\
\hline $\operatorname{MAN}(-1)$ & $-0.1637 * * *(-2.96)$ & $-0.2684 * * *(-3.35)$ & $-0.3092 * * *(-3.98)$ & $-0.3203 * * *(-4.12)$ & $-0.2693 * * *(-3.16)$ & $-0.3186^{* * *}(-4.12)$ \\
\hline $\operatorname{REER}(-1)$ & $-0.0002 * * *(-3.80)$ & $-0.0194 * * *(-3.96)$ & $-0.0223 * * *(-4.67)$ & $-0.0209 * * *(-3.85)$ & $-0.0278 * * *(-3.79)$ & $-0.0223 * * *(-4.69)$ \\
\hline TARIF_MAN(-1) & & $0.0566^{*}$ & $0.0560^{*}$ & $0.0971^{*}$ & $0.1311^{* *} \quad(2.23)$ & $0.0710 * * \quad(2.25)$ \\
\hline TARIF_MAN $(-1)^{4 Q 3}$ & & 0.0211 & $0.0304 * *$ & 0.0220 & $0.0266^{*} \quad(1.71)$ & $0.0328 * * * \quad(2.70)$ \\
\hline GROWTH(-1) & & & $0.0462 * *$ & $0.0641^{* * *}$ & $0.0750 * * * \quad(3.45)$ & $0.0636 * * * \quad(3.41)$ \\
\hline PPI_MAN(-1) & & & & 0.0020 & -0.0048 & \\
\hline MAN_WORLD(-1) & & & & & $-0.3080 \quad(-1.39)$ & \\
\hline Sample: & & & $1996 Q 4$ to $2012 Q 4$ & (65 observations) & & \\
\hline Adj. $R^{2}$ & 0.57 & 0.59 & 0.63 & 0.63 & 0.64 & 0.63 \\
\hline Schwarz crit. & 0.38 & 0.45 & 0.39 & 0.46 & 0.49 & 0.38 \\
\hline BG(4) prob. & 0.48 & 0.25 & 0.35 & 0.49 & 0.29 & 0.25 \\
\hline Jarq.-Bera prob. & 0.60 & 0.62 & 0.85 & 0.91 & 0.92 & 0.97 \\
\hline Arch(1) prob. & 0.78 & 0.78 & 0.83 & 0.68 & 0.55 & 0.51 \\
\hline Ramsey LR prob. & 0.67 & 0.67 & 0.18 & 0.43 & 0.28 & 0.22 \\
\hline Wu-Hausm. prob. & 0.59 & 0.49 & 0.56 & 0.16 & 0.35 & 0.29 \\
\hline Bounds F-stat. & $7.30 * *$ & $4.58^{* *}$ & $5.46 * * *$ & $5.12 * * *$ & $4.75^{* * *}$ & $5.92 * * *$ \\
\hline Bounds t-stat. & $-2.96^{*}$ & -3.35 & $-3.98^{*}$ & $-4.12^{*}$ & -3.16 & $-4.12 * *$ \\
\hline
\end{tabular}

This table summarizes the results of our ARDL-models for the share of GDP of Colombia's manufacturing sector. The table notes are the same as those for Table 1, with the following exceptions: $s^{4 Q 3}$ indicates the shift component of a variable with the third quarter of 2004 as the date of the structural break, MAN is the manufacturing sector's share, TARIF_MAN is the applied weighted mean tariff rate for manufactured products, GROWTH is the average OECD GDP growth rate, PPI_MAN is the producer price index for the manufacturing sector, and MAN_WORLD is the unweighted average of the manufacturing sector's global share. The $5 \%$ critical values for the bounds cointegration test with unrestricted intercept and no trend are $\mathrm{F}=$ 5.73, $\mathrm{t}=3.22(\mathrm{k}=1) ; \mathrm{F}=4.35, \mathrm{t}=3.78(\mathrm{~K}=3) ; \mathrm{F}=4.01, \mathrm{t}=3.99(\mathrm{k}=4)$ - Pesaran et al. $(2001)$.

The control variables, weighted manufacturing import tariffs and OECD growth rates, also have the expected sign and are significant (see Table 3 (ii) to (iv)), with a maximum MCI of approximately $-0.45 \mathrm{pp}$ (see Table 2, lower part). This finding suggests that many Colombian producers still have a competitive gap with foreign producers and that more innovation is necessary to reap more benefits from existing free trade agreements. A further noteworthy finding, which strengthens our EDD hypothesis, is that the decline of the manufacturing sector cannot be explained by the global trend toward services (the variable MAN_WORLD is not significant).

The results of the agricultural model are very similar to the ones of the manufacturing model. The variable REER is highly significant, has the expected sign in all specifications, 
and explains most of the decline (compare model (i) in Table 4 with the other models in this table), which implies that the overvaluation of the REER also caused an EDD syndrome in the agricultural sector. A possible explanation why the REER is not significant prior to the break could be the demand elasticity for agricultural products: apparently, Colombia's agricultural sector is not benefiting from depreciation, but is suffering from appreciation. In addition to the REER, the weighted import tariffs and OECD growth rates are also significant (the latter variable only has the expected sign after the break though ${ }^{19}$ ). Finally, both a change in production costs and the declining global share of the agricultural sector are not significant during the sample period.

\section{Table 4}

Model for the agricultural sector's share in the GDP of Colombia

\begin{tabular}{|c|c|c|c|c|c|c|}
\hline & (i) & (ii) & (iii) & (iv) & (v) & (vi) \\
\hline$\triangle \mathrm{TCR}$ & $-0.0137^{* *} \quad(-2.38)$ & $\mid-0.0138 * * \quad(-2.49)$ & $-0.0146 * * *(-2.69)$ & $\mid-0.0145 * * \quad(-2.65)$ & $-0.0141^{* *} \quad(-2.60)$ & $\mid-0.0147 * * *(-2.87)$ \\
\hline$\Delta \operatorname{REER}(-2)$ & $0.0141^{* *} \quad(2.58)$ & 0.0096 & 0.0048 & 0.0039 & 0.0040 & \\
\hline$\triangle \operatorname{REER}(-4)$ & $0.0109 * * \quad(2.06)$ & $0.0089 *$ & 0.0048 & 0.0046 & 0.0027 & \\
\hline AGR(-1) & $-0.4961 * * *(-4.30)$ & $-0.5866 * * *(-4.87)$ & $-0.6114^{* * *}(-5.10)$ & $-0.6235^{* * *}(-5.02)$ & $-0.6261 * * *(-5.09)$ & $-0.6074 * * *(-5.22)$ \\
\hline $\operatorname{AGR}(1)^{\mathrm{s} 3 Q 3}$ & $0.1573^{* * *} \quad(3.94)$ & $0.1597^{* * *} \quad(4.13)$ & $0.1499 * * * \quad(3.90)$ & $0.1418^{* * *} \quad(3.35)$ & $0.1534^{* * *} \quad(3.60)$ & $0.1399 * * * \quad(3.83)$ \\
\hline $\operatorname{REER}(-1)^{5303}$ & $-0.0226 * * *(-4.28)$ & $-0.0215^{* * *}(-4.18)$ & $-0.0223 * * * \quad(-4.39)$ & $-0.0213^{* * *}(-3.86)$ & $-0.0236 * * * \quad(-4.14)$ & $-0.0210^{* * *}(-4.33)$ \\
\hline TARIF_AGR(-1) & & $0.0484 * \quad(2.00)$ & $0.0528 * * \quad(2.23)$ & $0.0485 * \quad(1.95)$ & 0.0398 & \begin{tabular}{|ll}
$0.0598^{* * *}$ & $(2.78)$ \\
\end{tabular} \\
\hline GROWTH(-1) & & & $-0.0507 * \quad(-1.90)$ & $\begin{array}{ll}-0.0571^{*} & (-1.87)\end{array}$ & -0.0463 & $\mid-0.0587^{* *} \quad(-2.33)$ \\
\hline GROWTH(-1) $)^{5303}$ & & & $0.0645^{* *} \quad$ (2.14) & $0.0698 * * \quad(2.13)$ & $0.0631^{*}$ & $0.0763^{* * *} \quad(2.79)$ \\
\hline PPI_AGR(-1) & & & & \begin{tabular}{|ll}
-0.0013 & $(-0.48)$
\end{tabular} & -0.0014 & \\
\hline AGR_WORLD(-1) & & & & & -0.0472 & \\
\hline Sample: & & & $2000 Q 1$ to $2012 Q 4$ & (52 observations) & & \\
\hline $\operatorname{Adj} . R^{2}$ & 0.30 & 0.35 & 0.38 & 0.37 & 0.38 & 0.40 \\
\hline Schwarz crit. & -0.73 & -0.74 & -0.69 & -0.62 & -0.59 & -0.82 \\
\hline $\mathrm{BG}(4)$ prob. & 0.15 & 0.55 & 0.30 & 0.14 & 0.14 & 0.76 \\
\hline Jarq.-Bera prob. & 0.54 & 0.53 & 0.53 & 0.58 & 0.50 & 0.65 \\
\hline $\operatorname{Arch}(1)$ prob. & 0.10 & 0.14 & 0.73 & 0.84 & 0.62 & 0.81 \\
\hline White prob. & 0.39 & 0.41 & 0.64 & 0.76 & 0.91 & 0.53 \\
\hline Ramsey LR prob. & 0.26 & 0.53 & 0.34 & 0.32 & 0.42 & 0.30 \\
\hline Wu-Hausm. prob. & 0.99 & 0.91 & 0.96 & 0.91 & 0.83 & 0.86 \\
\hline Bounds F-stat. & $7.04^{* * *}$ & $6.63^{* * *}$ & $5.46^{* * *}$ & $4.60^{* * *}$ & $4.36^{* * *}$ & $5.89^{* * *}$ \\
\hline Bounds t-stat. & $-4.29 * * *$ & $-4.83 * * *$ & $-5.20 * * *$ & $-4.82^{* *}$ & $-4.77 * *$ & $-5.47^{* * *}$ \\
\hline
\end{tabular}

This table summarizes the results of our ARDL-models for the share of the agricultural sector in Colombia's GDP. The table notes are the same as those in Tables 1 and 3, with the following exceptions: $s^{303}$ indicates the shift component of a variable with the third quarter of 2003 as the date of the structural break, AGR is the agricultural sector's share, TARIF_AGR is the applied weighted mean tariff rate for agricultural products, PPI_AGR is the producer price index for the agricultural sector, and AGR_WORLD is the unweighted average of the agricultural sector's global share. The 5\% critical values for the bounds cointegration test with unrestricted intercept and no trend are $\mathrm{F}=4.85, \mathrm{t}=3.53(\mathrm{k}=2)$-Pesaran et al. (2001). 
The MCI suggest that the appreciation of the REER had a maximum impact of $-0.80 \mathrm{pp}$ between the first quarter of 2004 and the last quarter of 2012, whereas the lowering of the tariff rates and lower growth rates "only" had a maximum impact of $-0.27 \mathrm{pp}$ and $-0.13 \mathrm{pp}$ (see Table 2, lower part). An explanation for the result that decreasing tariffs in the agricultural sector had less impact than in the manufacturing sector may be that the former sector received substantive subsidies in recent years (with the aim to reduce possible negative impacts of the REER appreciation).

\section{CONCLUSIONS}

In this paper, the "conventional Dutch Disease" concept of Corden and Neary (1982) has been extended to consider that boom-related exports and inflows of capital together might lead to an overvaluation of the REER in Colombia, which in turn had an adverse effect on the competitiveness of its lagging sectors - manufacturing and agriculture. Accordingly, the appreciation of the REER is not only considered an outcome of the declining importance of the lagging tradable sectors as in the "conventional" theory, but also as a cause for sectoral recomposition.

The obtained results suggest that changes in relative productivity - the BalassaSamuelson effect - explain most of the appreciation of Colombia's REER between 2004 and 2012. Further noteworthy findings are that relative government expenditure had no significant impact on the REER, whereas interest rate differentials had a persistent effect. The latter finding is in line with Ibarra (2011) and implies that the Colombian central bank could reduce its intervention interest rate to prevent a further appreciation or facilitate a depreciation in the REER. It has to be kept in mind though that the impact of interest rate differentials was minor during our sample period.

Our most important findings are (i) that Colombia's increasing commodity exports and the boom-related surge in capital inflows also contributed significantly to the appreciation of Colombia's REER and (ii) that the resulting overvaluation was the most important reason for the decline of the share of the manufacturing and agricultural sector in the 
country's GDP during the boom period. This declining share of lagging sectors cast doubt on the sustainability of Colombia's resource-based growth model because the decreasing diversification of its economy makes the country very vulnerable to external demand and price shocks. Moreover, a strong manufacturing sector is often considered very important to achieve sustainable long-term growth because of positive spillover effects, higher value added, and innovation, which might explain why most developing countries that managed to catch-up with richer countries were manufacturing exporters (Sachs and Warner, 2001; Chang, 2002; Rodrik, 2007). Hence, developing countries that wish to emulate the "Colombian model" and attract massive foreign capital inflows should be cautious and consider that EDD effects might also occur in their economies.

Further weaknesses of Colombia's current growth model are that approximately $50 \%$ of its exports are dependent on oil even though its reserves will last only for less than seven years if it continues to produce at the current rate $^{20}$ and that huge proportions of the boomrelated profits are repatriated (in 2012, Colombia paid dividends of approximately US\$ 16 billion to foreign investors). Thus, it appears vital for the long-term development of the country to increase its share of boom-related profits and to ensure that these revenues are used for the improvement of its innovative capacities and the productivity of lagging sectors, thereby enabling the country to compete successfully in markets that are not related to fuel or mining. According to our sectoral models, this latter aspect is particularly important in the Colombian case as the lowering of import tariffs and sluggish global growth figures also contributed to the decline of its manufacturing and agricultural sector.

\section{References}

Aguirre, A. and Calderón, C. (2005). 'Real exchange misalignments and economic performance'. Central Bank of Chile Working Paper No. 315.

Arezki, R. and van der Ploeg, F. (2011). Do natural resources depress income per capita?. Review of Development Economics, Vol. 15(3), pp. 504-21.

Arias, M., Atienza, M. and Cademartori, J. (2013). Large mining enterprises and regional development in Chile: between the enclave and cluster. Journal of Economic 
Geography, published online May 3, doi: 10.1093/jeg/lbt007.

Banco de la República (2013). 'Balanza de pagos de Colombia a partir de 1994'. Retrieved at 17 July 2013 from http://www.banrep.gov.co/es/info-temas-a/2293.

Bayangos, V.B. and Jansen, K. (2011). Remittances and Competitiveness: The Case of the Philippines. World Development, Vol. 39(10), pp. 1834-1846.

Belke, A., Bordon, I.G. and Volz, U. (2013). Effects of Global Liquidity on Commodity and Food Prices. World Development, Vol. 44(April): 31-43.

Bourdet, Y. and Falck, H. (2006). Emigrants' remittances and Dutch Disease in Cape Verde. International Economic Journal, Vol. 20(3), pp. 267-284.

Bresser Pereira, L.C. (2008). The Dutch Disease and its neutralization: a Ricardian approach. Brazilian Journal of Political Economy, Vol. 28(1), pp. 47-71.

Bresser Pereira, L.C. (2009). The Tendency of the Exchange Rate toward Overvaluation. In Globalization and Competition, Cambridge: Cambridge University Press: 125-147.

Brunnschweiler, C.N. (2008). Cursing the Blessings? Natural Resource Abundance, Institutions, and Economic Growth. World Development, Vol. 36(3): 399-419.

Chang, H.-J. (2002). Kicking away the ladder: Development Strategy in Historical Perspective. London: Anthem Press.

Clavijo, S., Vera, A. and Fandiño, A. (2012). La desindustrialización en Colombia: Análisis cuantitativo de sus determinantes. Bogotá: ANIF.

Commission on Sustainable Agriculture and Climate Change (2012). Final Report: Achieving food security in the face of climate change. Copenhagen: CGIAR Research Program on Climate Change, Agriculture and Food Security.

Corden, W.M. (1984). Booming Sector and Dutch Disease Economics: Survey and Consolidation. Oxford Economic Papers, Vol. 36(3), pp. 359-380.

Corden, W.M. and Neary, P. (1982). Booming Sector and De-Industrialisation in a Small Open Economy. The Economic Journal, Vol. 92(368), pp. 825-848.

Echavarría, J.J., López, E. and Misas, M. (2008). La tasa de cambio real de equilibrio en Colombia and su desalineamiento: estimación a través de un modelo SVEC. Ensayos sobre Política Económica, Vol. 26(57), pp.282-319.

Eichengreen, B. (2007). 'The Real Exchange Rate and Economic Growth'. Commission on Growth and Development Working Paper No. 4.

Fielding, D. and Gibson, F. (2013). Aid and Dutch Disease in Sub-Saharan Africa. Journal of African Economies, Vol. 22(1), pp.1-21.

Frenkel, R. and Rapetti, M. (2012). External Fragility or Deindustrialization: What is the 
Main Threat to Latin American Countries in the 2010s?. World Economic Review, Vol. 1(1), pp. 37-56.

Gelb, A. (1988). Oil Windfalls: Blessing or Curse?. New York: Oxford University Press.

Gylsafon, T. (2001). Natural Resources, Education and Economic Development. European Economic Review, Vol. 45(4-6), pp. 847-859.

Hansen, B.E. (1997). Approximate Asymptotic P Values for Structural-Change Tests. Journal of Business and Economic Statistics, Vol. 15(1), pp. 60-67.

Hodge, D. (2012). 'The Exchange Rate, Dutch Disease and Manufacturing in South Africa: What do the Data Say?'. ERSA Working Paper No. 281.

Ibarra, C.A. (2011). Capital Flows and Real Exchange Rate Appreciation in Mexico. World Development, Vol. 39(12), pp. 2080-2090.

Irwin, C. (2013). Mexican Political Parties Align Behind Energy Sector Reform. Breaking Energy, [online] Available at: <http://breakingenergy.com/2013/07/09/mexicanpolitical-parties-align-behind-energy-sector-reform/> [Accessed 9 August 2013].

Larsen, E.R. (2006). Escaping the Resource Curse and the Dutch Disease? When and Why Norway Caught Up with and Forged Ahead of Its Neighbors. American Journal of Economics and Sociology, Vol. 65(3): 605-640.

Lartey, E. (2011). Financial Openness and the Dutch Disease. Review of Development Economics, Vol. 15(3), pp.556-568.

Lartey, E., Mandelman, F. and Acosta, P. (2012). Remittances, Exchange Rate Regimes and the Dutch Disease: A Panel Data Analysis. Review of International Economics, Vol. 20(2), pp.377-395.

Lederman, D. and Maloney, W.F. (2007). Natural Resources: Neither Curse nor Destiny. Washington, DC: World Bank and Stanford University Press.

Lederman, D. and Maloney, W.F. (2008). In Search of the Missing Resource Curse. Economia, Vol. 9 (1), pp. 1-39.

Lopez, A. (2012). Los recursos nacionales and el debate sobre la industrialización en América Latina. In Albrieu, R., López, A. and Rozenwurcel, G. (eds.): Los recursos naturales como palanca del desarrollo en América del Sur: ¿Ficción o realidad?. Montevideo: Red Mercosur, pp.23-48.

Naceur, S.B., Bakardzhieva, D. and Kamar, B. (2012). Disaggregated Capital Flows and Developing Countries' Competitiveness. World Development, Vol. 40(2), pp. 223-237.

Pesaran, M.H. and Shin, Y. (1995). 'An Autoregressive Distributed Lag Modeling Approach to Cointegration Analysis'. University of Cambridge Working Paper No. 9514. 
Pesaran, M.H., Shin, Y. and Smith, R.J. (2001). Bounds Testing Approaches to the Analysis of Level Relationships. Journal of Applied Econometrics, Vol. 16(3), pp.289326.

Prebisch, R. (1950). The Economic Development of Latin America and its Principal Problems. Economic Bulletin for Latin America, Vol. 7(1), pp.1-22.

Rajan, R.G. and Subramanian, A. (2011). Aid, Dutch Disease, and Manufacturing Growth. Journal of Development Economics, Vol. 94(1), pp. 106-118.

Rodrik, D. (2007). How to save globalization from its cheerleaders. The Journal of International Trade and Diplomacy, Vol. 1(2): 1-33.

Rodrik, D. (2008). The real exchange rate and economic growth. Brookings Papers on Economic Activity, Vol. 39(2), pp. 365-439.

Saborowski, C. (2009). 'Capital Inflows and the Real Exchange Rate: Can Financial Development Cure the Dutch Disease?'. IMF Working Paper No. 09/20.

Sachs, J.D. and Warner, A. (1995, revised in 1997). 'Natural Resource Abundance and Economic Growth'. NBER Working Paper No. 5398.

Sachs, J.D. and Warner, A. (2001). The Curse of Natural Resources. European Economic Review, Vol. 45(4-6), pp. 827-38.

Shin, Y., Yu, B. and Greenwood-Nimmo, M.J. (2013). Modelling Asymmetric Cointegration and Dynamic Multipliers in a Nonlinear ARDL Framework. In Horrace, W.C. and Sickles, R.C. (eds.): Festschrift in Honor of Peter Schmidt. New andork: Springer Science \& Business Media.

Szirmai, A. and Verspagen, B. (2011). 'Manufacturing and Economic Growth in Developing Countries, 1950-2005'. UNU-MERIT Working Paper No. 69.

Szirmai, A., Naudé, W. and Alcorta, L. (2013). Pathways to Industrialization in the Twenty-First Century: New Challenges and Emerging Paradigms. Oxford: Oxford University Press.

Treviño, J.P. (2011). 'Oil-Price Boom and Real Exchange Rate Appreciation: Is There Dutch Disease in the CEMAC?'. IMF Working Paper No. 11/268.

\footnotetext{
${ }^{1}$ The sharp decline in the agricultural sector's share between 1999 and 2000 was most likely caused due to a methodological change in Colombia's National Institute of Statistics (DANE). However, the post-2002 decline is not caused by a similar issue, but is "real" and well documented.

${ }^{2}$ Lederman and Maloney (2008) and Lopez (2012) argue that the success of a country with an abundance of raw material depends on the coexistence of the commodity sector with
} 
other sectors as this ensures that its exports base is sufficiently diversified and technology can spillover to other industries.

${ }^{3}$ Note that that our EDD concept is different from the EDD concept introduced by Bresser Pereira (2008). In our case, EDD refers to an appreciation of the REER that is related to a natural resource boom, whereas Bresser Pereira's concept is based on the notion that the exploitation of cheap labor might lead to Dutch Disease effects.

${ }^{4}$ According to the ADF test, half the variables in this study are intrinsically I(1). It is well known that the ADF test has low power but the inspection of the data also suggest the nonstationarity of some variables.

${ }^{5}$ As we allow parameter shifts, our model has potentially twice as many variables in the cointegration equation.

${ }^{6}$ A further advantage of this type of model is that it can easily be adapted to allow for structural shifts by including zero-one dummy variables (Shin, 2013).

${ }^{7} \mathrm{We}$ attempted to estimate agricultural shares for the pre-2000 period by retropolation (taking into account the growth rates of the agricultural sector between 1996Q1 and 1999Q4). However, the modeling results for these estimated shares are very sensitive to small changes in the sample period. Therefore, we decided to use a shorter sample period for this sector.

${ }^{8}$ To check for the robustness of our results we also re-estimated our parsimonious models (Table 1 (vii) and Table 4 and 5 (vi)) over two different sample periods: 1999Q1 to 2012Q4 and 1996Q1 to 2009Q4 in the case of the REER and manufacturing model, and 2002Q1 to 2012Q4 and 2000Q1 to 2010Q4 for the agriculture model. Overall our models are stable and estimating them over these shorter sample periods does not introduce misspecification. We are therefore confident that our main conclusions are robust and not biased by the sample period chosen.

${ }^{9}$ The average share of manufacturing and agriculture in other countries, and the PPP values were interpolated to quarterly frequency with the "cubic match last" method as they are only available annually.

${ }^{10}$ The Colombian data were seasonally adjusted with the X12 method (readily available in EViews).

11 The PPP values for the period 1996 to 2010 are retrieved from the Penn World Tables 7.1, whereas they are estimated for 2011 and 2012 according to the GDP at PPP growth rates that are reported by the World Bank. 
${ }^{12} \mathrm{We}$ would have liked to consider the Colombian inter-bank rate instead of the lending rate. Unfortunately, this rate is only reported from 2002 onward.

13 The tariff rates are only available on an annual basis. Since it is not clear if they change much within a year (and at what point in time), we apply the annual rates for all quarters of the respective year. For the year 2012, no data are reported at the time of writing this paper. Thus, we apply the 2011 rates for the year 2012 .

14 The Maximum Likelihood Ratio F-statistics probabilities (calculated using Hansen's (1997) method) were the following: REER model $=0.096$, manufacturing model $=0.005$, and agricultural model $=0.062$.

15 Since the models that include shift variables have a superior fit, only these models are reported in the results section.

16 The unexpected sign and the low t-statistic of the lagged-level foreign reserves variable suggest that the foreign exchange market intervention by the Colombian Central Bank was not effective during the sample period (from 2010 onward daily interventions were made to achieve a depreciation of the Colombian Peso).

${ }^{17}$ Model (vi) has a higher $\mathrm{R}^{2}$ than model (vii), but the latter is our favored parsimonious model because of the lower Schwarz criterion and because it is more stable if the sample period is shortened.

18 Their main argument is that in financially more developed countries, FDI is mainly used to finance the development of capital intensive industries that often produce tradables, whereas in financially less-developed countries the resources are often used for nontradables, thereby leading to a greater appreciation of the currency.

${ }^{19}$ The demand elasticity for agricultural products could be also an explanation for this finding, i.e. apparently the agricultural sector is negatively affected by lower global growth but not positively by higher growth.

${ }^{20}$ According to International Energy Statistics (August 2013), Colombia's daily production is approximately one million barrel per day and its proven reserves are approximately 2.2 billion barrels. 